\title{
The Impact of Financial Preparation and Disaster Experience on Households' Disaster Risk Perception: Empirical Evidence from Quang Binh Province, Vietnam
}

\author{
Tam T. Le ${ }^{1}$, Trang T.H. Thai ${ }^{2}$, Thao P. Do ${ }^{3}$, Nga T.V. Nguyen ${ }^{4}$, Huyen T. Hoang ${ }^{5}$ \\ ${ }^{1,2,3,4}$ School of Banking and Finance, National Economics University, Vietnam \\ ${ }^{5}$ Faculty of Banking and Finance, Nghe An College of Economics, Vietnam
}

Corresponding Author: Tam T. Le

\begin{abstract}
This paper is aimed at analysing the impacts of financial preparation and disaster experience on households' disaster risk perception, including perceptions of likelihood and severity in Quang Binh Province of Vietnam, one of the areas strongly affected by natural disasters and climate change. With the data from direct surveying 308 households in Quang Binh province, the research methodology includes Cronbach's Alpha, EFA and OLS regression models. The key findings are: First, disaster experience has positive impact on natural disaster risk perception. Second, financial preparation has negative impact on natural disaster risk perception. Third, the risks of natural disasters in Quang Binh Province are increasing and unpredictable due to rapid economic growth and urbanization. This fact requires the Government, provincial committees, and stakeholders to go beyond traditional coping methods, implement more customized policies and specific actions to try to reduce the risks of natural disasters.
\end{abstract}

Keywords: disaster risk, disaster risk perception, financial preparation, disaster experience

\section{INTRODUCTION}

In Vietnam, natural disasters have the most serious consequences, negatively affecting people's lives mainly due to floods. In particular, the North Central region of Vietnam is the place that suffers the most storms and floods in the year. In terms of the area selected for the study is Quang Binh province, one of the provinces in the North Central of Vietnam. Quang Binh Province has been frequently affected by historic floods. Especially in 2020, the total damage of the province is 3,500 billion VND and 25 people were killed, 197 people were injured and many houses, gardens, farms were destroyed. These are the most alarming and devastating figures in the history of recent years affected by floods in Quang Binh province.

This study is focused households from flood-affected areas in Quang Binh province between October $6^{\text {th }}, 2020$ and December $1^{\text {st }}, 2020$ - the period when central coastal provinces of Vietnam, including Quang Binh province, witnessed the devastation of a new historic flood recorded after more than 40 years. In addition, the study explores the development of an indicator system of households' financial preparedness from the point of view of their internal and external coping capacities. Furthermore, it uses statistical models to explore the correlation between households' financial preparedness or experience through a disaster and disaster risk perception. This study is aimed at: (1) understanding factors affecting the household's perception of disaster risk, focusing on financial preparation and disaster experiences; (2) analyzing the 
Tam T. Le et.al. The impact of financial preparation and disaster experience on households' disaster risk perception: empirical evidence from Quang Binh Province, Vietnam.

impact of households' financial preparedness, disaster experiences and disaster perception through quantitative methods; (3) proposing some recommendations to raise stronger awareness on natural disasters and natural disaster prevention of households.

\section{LITERATURE REVIEW}

\subsection{Households' disaster risk perception}

Disaster risk is defined as the product of the hazard occurring, the vulnerability and the degree of loss (Kron, 2002; Barredo et al, 2007). Kron (2002) confirmed that disaster risk consists of three components: Hazard, Vulnerability and Exposure.

\section{RISK = HAZARD $x$ VULNERABILITY $x$ EXPOSURE}

Of which, the Hazard is defined the threatening natural event including its probability of occurrence. Vulnerability is the lack of resistance to damaging forces and Exposure is the values that are present at the location involved.

$$
\text { Research 'Disaster Risk }
$$

Perception" was first published in the 1940s, when Gilbert White found people's adjustment to floods in the United States. $\mathrm{He}$ found that people's past experiences with floods directly influenced their behavior when they were under threat from a possible flood. Slovic (1987) assumed that flood risk perception is the intuitive assessment and subjective feeling of individuals or groups on risks under the background of limited and uncertain information.

In 2008, Raaijmakers et al defined flood risk perception as a combination of three factors: awareness, preparation and anxiety. According to Bubeck (2012), the concept of "perceived risk" is a combination of possibility and severity of a certain event or activity. Wachinger et al (2013) suggested that flood risk perception is generally thought to involve the processing of information about the uncertainty surrounding the negative consequences from a future flood, which are evaluated using various probabilities.

Accordingly, the definition of disaster risk perception that we use in this research paper is 'Disaster risk perception is an intuitive assessment of an individual or a group based on awareness, emotion and behavior to judge the possibility and consequences when natural disaster occur'. We divided the disaster risk perception of residents who are under directly the potential threat of flood hazards into 2 dimensions: Possibility and Severity.

\subsection{Protection Motivation Theory (PMT)}

Protection Motivation Theory was proposed by Rogers (1975) as a theoretical framework to research the effect of resistance on fear. PMT was originally applied in health-risk studies to predict health behavior. Then, Rogers (1983) provided a psychological model widely applied to describe threat-related decisionmaking. It consists of four factors that determine self-defense and adaptive behavior: vulnerability to risk, severity of results, effectiveness of available countermeasures, and self-protection formula (Floyd, Prentice-Dunn and Rogers, 2000).

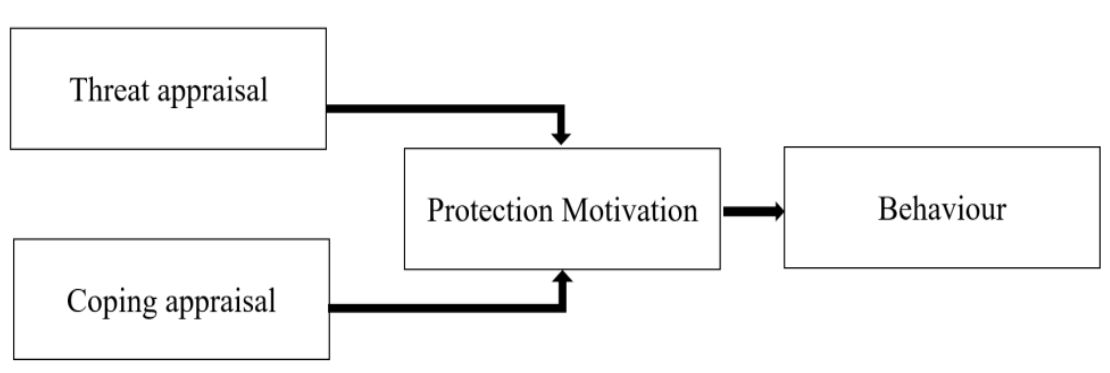

Figure 1: PMT theoretical model

Source: Rogers (1983) 
Tam T. Le et.al. The impact of financial preparation and disaster experience on households' disaster risk perception: empirical evidence from Quang Binh Province, Vietnam.

Other studies confirm that a higher

level of cognitive risk increases an individual's motivation to self-protect
(Kellens \& Terpstra 2012; Bubeck et al, 2017; Harlan et al 2019).

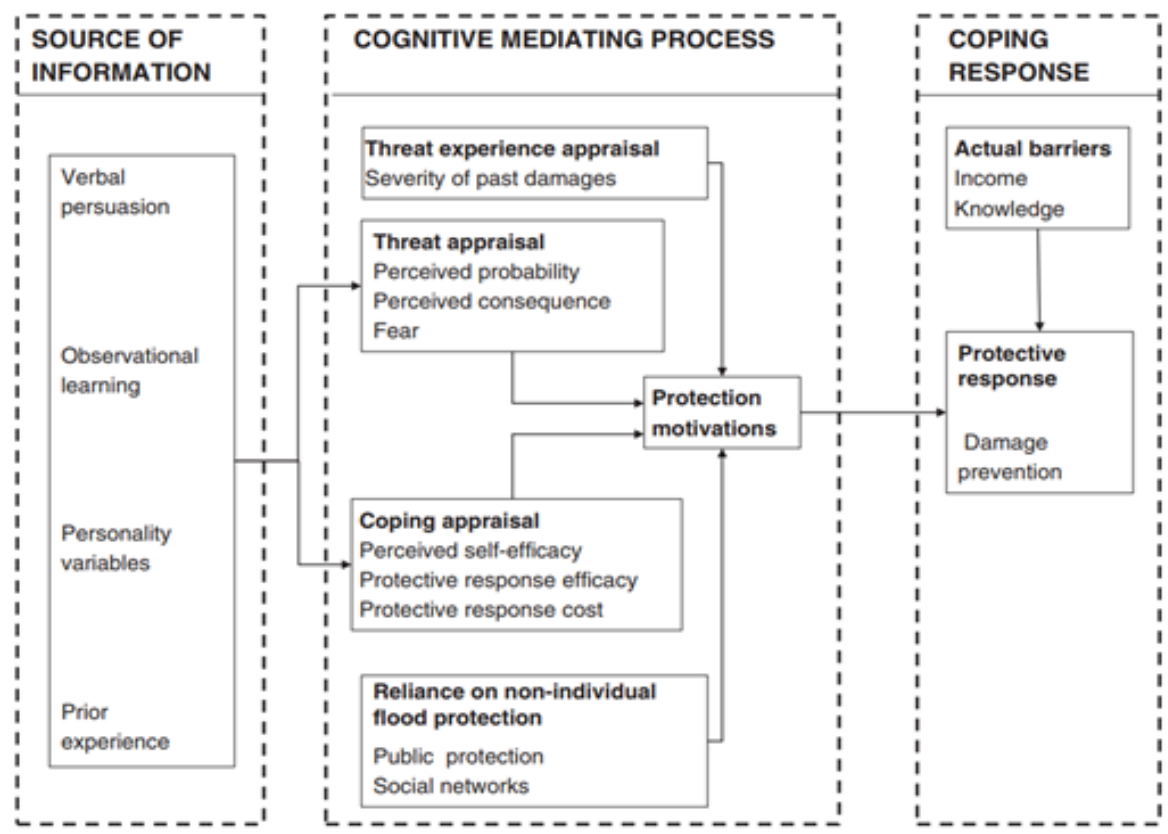

Figure 2: Schematic illustration of the extended PMT theory, adjusted by Grothmann and Reusswig to suit the flood context. Sources: Rogers (1983), Grothmann and Reusswig (2006)

Protection incentives derive from two intermediate processes that individuals use to assess hazards and to choose from among protection strategies, along with the cost of dealing with the risk. The hazard assessment process is based on perceptions of the likelihood of a hazard occurring, perception of the consequences of a hazard and fear as three indirect factors in influencing estimates of flood severity. The response level assessment takes place immediately after the hazard assessment and begins only if a specific hazard assessment threshold is passed. The coping level assessment process also has three components: awareness of their own capabilities, effectiveness of prevention and the cost of dealing with it.

This process starts only if the threat is specifically assessed. It includes public awareness that protection actions will be effective, and the cost of implementing protection. In PMT, the hazard assessment and coping process work together resulting in an incentive to protect against a certain risk, such as floods. They assume that the incentive to protect depends on two additional groups of factors, the hazard experience assessment and the concentrated flood prevention. A hazard experience assessment is the process of assessing the severity of a flood in the past by households. There are many reasons why experiencing hazards in the past can give households an incentive to prevent flooding in the future.

The incentive for disaster preparedness is also related to households' dependence on centralized flood protection. Households are less likely to undertake preventive action if their government agency succeeds in implementing flood control programs or management policies aimed at mitigating floods - the centralized management policy effect. The empirical findings of the study using Motivational Protection Theory to investigate the preventive measures of households living in floodplain areas are as follows. Firstly, the coping level assessment component is often considered a determinant of flood prevention behavior. In contrast, a hazard 
Tam T. Le et.al. The impact of financial preparation and disaster experience on households' disaster risk perception: empirical evidence from Quang Binh Province, Vietnam.

assessment factor is often thought to have a lower explanatory significance (Bubeck, 2012). Secondly, mixed evidence is found regarding the relationship between disaster risk perception and the application of individual mitigation measures. Botzen \& Berg (2012) observed a positive relationship between risk perception and people's intention to invest in sandbags for retaining walls. Similarly, Terpstra 2013, reports that an increase in awareness of risk vulnerability leads to intentions of implementing risk mitigation behaviors. This positive effect has been found by Wachinger et al. (2013), who highlight the difficulties in establishing causal relationships between risk perception and preventive behaviors from typical data of a moment. Thirdly is that the flood experience is almost always significant and has a positive relationship with individual mitigation measures. As observed, the rate of implementation of preventive measures is significantly increased when natural disasters occur.

\subsection{Financial preparation}

Disaster financial preparation is understood as a series of behaviors aimed at disaster avoidance and post-disaster reconstruction of the people based on a financial perspective that includes two aspects, that is, external financial support and the financial preparedness of households living in disaster-affected areas.

In 2008, Miceli et al. stated: The disaster was assessed with a set of questions designed to identify the type and number of protection behaviors employed by the population in response to a likely flood disaster. Kirschenbaum (2017) suggested that people's preparation for disaster prevention can be directly measured by asking people if they are fully prepared for disaster preparedness. Hoffmann and Muttarak (2017) measure disaster preparedness by asking people if they have prepared an emergency disaster preparedness kit (such as flashlight, radio, clean water) or have had a family evacuation plan yet. Or whether they buy insurance as studied by Xu et al. (2018).

Based on a number of studies addressing the establishment of people's financial preparedness (Armas, 2006; Becker et al., 2012; Lo \& Cheung, 2015; Bubeck et al., 2012; Keil et al., 2008 ; Le Dang et al. 2014), the research team used a scale with two main factors, "Internal coping ability" and "External coping ability" to measure and fully reflect the components in disaster financial preparation for households in Quang Binh province.

\subsection{Households' disaster experiences}

In this article, the research team will define disaster experience as the knowledge and lessons learned from each person after having experienced a disaster or more.

According to Barnett \& Breakwell (2001), households' natural disaster experience is measured by breaking down into three sub-dimensions: (1) the frequency of previous experiences; (2) the extent to which that experience affects life; (3) the results show whether the individual considers that impact positive or negative. Lindell et al.(2013), in the study of North American households' response to environmental risks, identified that experience of risk can be determined by measuring the and the frequency and frequency of casualties and damages suffered by respondents themselves, family members, or friends, neighbors, or coworkers. Tian et al. (2014) suggest that earthquake experience can be defined as the number of earthquakes; damages or losses from previous earthquakes and the experience of those damages or losses by the respondent or friends or family. Or most recently, Donner (2018) said that experience is the total number of natural disasters that respondents have experienced in the past.

In general, most of the approaches that scholars have used are related to the number of disasters experienced, the extent of property damage. This is a measure of tangible experience, based on a material point of view. This study also applies the 
Tam T. Le et.al. The impact of financial preparation and disaster experience on households' disaster risk perception: empirical evidence from Quang Binh Province, Vietnam.

measurement of disaster experience according to the above-mentioned scale.

\subsection{Impact of financial preparation on households' disaster risk perception}

In disaster prone areas, wellfinancially prepared families may underestimate the likelihood or impact of a disaster (Lo \& Cheung, 2015; Bubeck et al., 2012). Miceli et al. (2008) found that residents' disaster response behavior (including insurance purchases) was not significantly correlated with perceptions of flood disaster likelihood, but It is significantly positively associated with perceptions of the severity of flood disasters. $\mathrm{Xu}$ et al. (2018) found that residents' insurance behaviors were significantly positively correlated with the threat and likelihood of landslide disasters. Helweg-Larsen (1999), Paton \& Johnston (2001) found that those who are prepared to respond to disasters have a lower need for additional preparation than others.

\subsection{Impact of disaster experiences on households' disaster risk perception}

Disaster experiences have strong negative impacts on households' disaster risk perception. Weinstein (1998) identified the importance of past experiences to human disaster risk perception. Similarly, Botzen et al. (2009) found that people experiencing a flooding event were able to change their perceptions of risk, and that more people were motivated to take actions such as preparing for some natural disaster in the future.

Lawrence (2014) argued that inexperienced people who experience natural disasters tend to normalize their previous experiences and are therefore optimistic about the results of floods. Xu et al. (2019) showed that the greater the experience experienced by a disaster, the stronger the awareness of households about the severity of a disaster. And the most recent study by Gao et al. (2020) shows that households that perceive a less (more) risk when they experience disasters have a lower (higher) mortality rate. However, Whitmarsh (2008) argued that people who have experienced a flood are not as likely to be knowledgeable, interested or active in implementing behavioral responses to climate change, then people who have not experienced floods.

\subsection{Impact of households' demographic characteristics on households' disaster risk perception}

Many studies have discovered that demographics strongly affect risk perception - with mixed results. Gender is closely related to risk perception in risky activities and activities (Slovic, 1999; O'Connor, Bord \& Fisher, 1999; Sundblad, Biel \& Garling, 2007; Brody et al, 2008). In terms of risks associated with climate change, women also tend to be more concerned than men (Finucane et al., 2000; Sund, Svensson \& Andersson, 2015). Linden (2015) identifies gender as an "important predictor" of climate change risk perception. Excluding other political, social and demographic variables in the regression model, women in the United States are more likely to be concerned with climate change than men (McCright, 2010; Hamilton, 2011).

For other demographic factors (such as age, education level, income), no consistent or relevant relationship to perceptions of climate change risk was found. Spence et al. (2011) No concrete evidence was found to suggest that living in areas commonly affected by climate change (geographic location) affects their perceptions of climate change risks. In this article, the research team does not make any hypotheses about the above correlation.

\section{Research Model and hypothesis 3.1. Research models}

The possibility of a natural disaster and the severity of the occurrence are the dependent variables of this study, which are the time interval variables, the study uses the ordinary least squares method (OLS) to estimate models when exploring the correlation between household financial 
Tam T. Le et.al. The impact of financial preparation and disaster experience on households' disaster risk perception: empirical evidence from Quang Binh Province, Vietnam.

preparedness of Quang Binh province or experience of a disaster and perceptions of disaster risk. The equation for the model is as follows:

$Y_{i}=\alpha_{0}+\beta_{1 i} \times$ Financial preparation $_{i}+\beta_{2 i}$
$\times$ Experience $_{i}+\beta_{3 i} \times$ Demographics $_{i}+\varepsilon_{i}$

In which: $\mathrm{Y}_{\mathrm{i}}$ is the dependent variable of the model, which can be divided into two components, namely Possibility and Severity; Financial preparation ${ }_{\mathrm{i}}$, Experience $_{i}$, and Demographics $_{i}$ represent financial preparation, disaster experience, and demographic variables, respectively; $\alpha_{0}$, $\beta_{1 \mathrm{i}}, \quad \beta_{2 \mathrm{i}}$ and $\quad \beta_{3 \mathrm{i}}$. Corresponding representatives for the estimated model parameters; and $\varepsilon_{\mathrm{i}}$ represents the remainder of the model (factors that have not been considered). SPSS 20.0 is software used to run the model.

\subsection{Research hypothesis}

Based on the research overview, the research team comes up with the following two hypotheses:

H1: Financial preparation has the negative impact on natural disaster risk perception

H2: Households' experiences on natural disasters has positive impact on their perception of natural disaster risk

Table 1: Variables and hypotheses

\begin{tabular}{|c|c|c|c|c|c|}
\hline & \multicolumn{2}{|c|}{ Variable name } & \multirow{2}{*}{$\begin{array}{l}\text { Meaning and measurement } \\
\text { Floooding is still going on at the end } \\
\text { of this year (according to the Likert } \\
\text { scale) }\end{array}$} & Hypothesis & References \\
\hline \multirow{6}{*}{$\begin{array}{l}\text { Dependent } \\
\text { variable }\end{array}$} & \multirow{3}{*}{ Possibility } & A1 & & & \multirow{6}{*}{$\begin{array}{l}\text { Slovic (1987), Lindell \& Whitney } \\
\text { (2000), Armas (2006), Solberg et al. } \\
\text { (2010), Lo (2013), Xu et al. (2016), } \\
\text { Sun \& Han (2018) }\end{array}$} \\
\hline & & A2 & $\begin{array}{l}\text { Flooding will continue in the coming } \\
\text { years }\end{array}$ & & \\
\hline & & A3 & $\begin{array}{l}\text { I always feel that floods will come at } \\
\text { any moment }\end{array}$ & & \\
\hline & \multirow{3}{*}{ Severity } & B1 & $\begin{array}{l}\text { I am worried about the devastating } \\
\text { impact of flooding on my village }\end{array}$ & & \\
\hline & & B2 & $\begin{array}{l}\text { The flood happened and destroyed } \\
\text { the property in my family }\end{array}$ & & \\
\hline & & B3 & $\begin{array}{l}\text { Floods occurred causing serious } \\
\text { damage to people's lives }\end{array}$ & & \\
\hline \multirow[t]{7}{*}{$\begin{array}{l}\text { Financial } \\
\text { preparation }\end{array}$} & \multicolumn{2}{|c|}{$\begin{array}{l}\text { Diversity of income } \\
\text { sources }\end{array}$} & $\begin{array}{l}\text { The diversity in household income } \\
\text { sources }\end{array}$ & $(-)$ & \multirow{8}{*}{$\begin{array}{l}\text { Armas (2006), Keil et al. (2008), } \\
\text { Becker et al. (2012), Paul and Bhuiyan } \\
\text { (2010), Bubeck et al. (2012), Le Dang } \\
\text { et al.(2014) and Lo \& Cheung (2015). }\end{array}$} \\
\hline & \multicolumn{2}{|l|}{ Income } & $\begin{array}{l}\text { Total household income on the Likert } \\
\text { scale }\end{array}$ & $(-)$ & \\
\hline & \multicolumn{2}{|l|}{ Deposits } & $\begin{array}{l}\text { Does the household have savings or } \\
\text { not }(0=\text { no, } 1=\text { yes })\end{array}$ & $(-)$ & \\
\hline & \multicolumn{2}{|c|}{$\begin{array}{l}\text { Loans from } \\
\text { financial institutions }\end{array}$} & $\begin{array}{l}\text { Can a household borrow money from } \\
\text { banks when a disaster occurs }(0=\text { no, } \\
1=\text { yes })\end{array}$ & $(-)$ & \\
\hline & \multicolumn{2}{|l|}{ Borrows } & $\begin{array}{l}\text { Can a household borrow money from } \\
\text { friends and relatives during a disaster } \\
(0=\text { no, } 1=\text { yes })\end{array}$ & $(-)$ & \\
\hline & \multicolumn{2}{|c|}{ Social insurance } & $\begin{array}{l}\text { Does the household buy insurance }(0 \\
=\text { no, } 1=\text { yes })\end{array}$ & $(-)$ & \\
\hline & \multicolumn{2}{|c|}{ Disaster insurance } & $\begin{array}{l}\text { Does the household buy disaster } \\
\text { insurance }(0=\text { no, } 1=\text { yes })\end{array}$ & $(-)$ & \\
\hline $\begin{array}{l}\text { Disaster } \\
\text { experiences }\end{array}$ & \multicolumn{2}{|l|}{ Experience } & $\begin{array}{l}\text { Severity of natural disaster } \\
\text { experienced by the household } \\
\text { (according to the Likert scale) }\end{array}$ & $(+)$ & \\
\hline
\end{tabular}

\section{RESEARCH RESULTS}

\subsection{Overview of natural disasters in Quang Binh Province, Vietnam}

Quang Binh is the sacred name of a land with a natural area of $8,065 \mathrm{~km} 2$ located in central Vietnam, where the natural and cultural elements of the South and the North converge. long history- cultural tradition, crystallization of unique spiritual and material cultural values.

Quang Binh is a province in the North Central region, where the East-West length is the narrowest of Vietnam. This place is one of the localities that suffer the most impacts with the highest frequency and the most devastating degree of natural 
Tam T. Le et.al. The impact of financial preparation and disaster experience on households' disaster risk perception: empirical evidence from Quang Binh Province, Vietnam.

disasters in Vietnam, especially hydrometeorological disasters. Common natural hazards in Quang Binh include floods, storms, tropical depressions, riverbank and coastal erosion (causing great damage); forest fires, severe cold, damaging cold, flying sand, sand fill and flash floods (causing great damage); sea level rise, cyclone, lightning, monsoon, hail, landslide (causing moderate damage); land subsidence, soil cracking, saltwater intrusion, etc. (causing slight damage).

\subsection{Descriptive statistic results}

Following are the research results.

Table 2: Descriptive Statistics

\begin{tabular}{|l|l|l|l|l|l|}
\hline & $\mathbf{N}$ & Minimum & Maximum & Mean & Std. Deviation \\
\hline Diversity of income sources & 308 & .20 & .80 & .2396 & 0.09338 \\
\hline Income & 308 & 1 & 5 & 3.09 & 1.184 \\
\hline Deposits & 308 & 0 & 1 & .49 & .501 \\
\hline Loans from financial institutions & 308 & 0 & 1 & .52 & .501 \\
\hline Borrows & 308 & 0 & 1 & .54 & .499 \\
\hline Social Insurance & 308 & 0 & 1 & .95 & .222 \\
\hline Disaster Insurance & 308 & 0 & 1 & .05 & .209 \\
\hline Experience & 308 & 1 & 5 & 2.70 & 1.119 \\
\hline Gender & 308 & 0 & 1 & .49 & .501 \\
\hline Age & 308 & 24 & 58 & 43.47 & 5.417 \\
\hline Education & 308 & 1 & 5 & 3.18 & 1.205 \\
\hline Occupation & 308 & 0 & 1 & .85 & .357 \\
\hline Duration of Residence & 308 & 1 & 58 & 35.85 & 13.895 \\
\hline Number of Family Members & 308 & 2 & 8 & 4.12 & 1.092 \\
\hline
\end{tabular}

Table 3: Cronbach's Alpha Results

\begin{tabular}{|c|c|c|c|c|}
\hline Factor & $\begin{array}{ll}\begin{array}{l}\text { Cronbach's } \\
\text { coefficient }\end{array} & \text { Alpha } \\
\end{array}$ & $\begin{array}{l}\text { Sentence } \\
\text { code }\end{array}$ & $\begin{array}{ll}\begin{array}{l}\text { Total } \\
\text { correlation }\end{array} & \text { variable } \\
\end{array}$ & $\begin{array}{l}\text { Cronbach's Alpha coefficient if variable is } \\
\text { eliminated }\end{array}$ \\
\hline \multirow[t]{3}{*}{ Possibility } & \multirow[t]{3}{*}{0.755} & A1 & 0.676 & 0.577 \\
\hline & & A2 & 0.501 & 0.770 \\
\hline & & A3 & 0.589 & 0.667 \\
\hline \multirow{3}{*}{ Severity } & \multirow[t]{3}{*}{0.727} & B1 & 0.527 & 0.677 \\
\hline & & B2 & 0.532 & 0.660 \\
\hline & & B3 & 0.601 & 0.588 \\
\hline
\end{tabular}

The variables of Possibility and Severity have Cronbach's Alpha coefficients of 0.755 and 0.727 , respectively, indicating that the scale can be used. The matched variables were further used for analysis in the next steps. Since the total correlation coefficient of all variables is greater than 0.3 , the explanatory results are all significant.

Table 4: Result of exploratory factor analysis (EFA) of dependent variable

\begin{tabular}{|l|l|l|}
\hline \multirow{2}{*}{} & Component \\
\cline { 2 - 3 } & $\mathbf{1}$ & $\mathbf{2}$ \\
\hline $\mathrm{A} 1$ & .869 & \\
\hline $\mathrm{A} 3$ & .837 & \\
\hline $\mathrm{A} 2$ & .741 & .841 \\
\hline $\mathrm{B} 3$ & & .803 \\
\hline $\mathrm{B} 2$ & & .762 \\
\hline $\mathrm{B} 1$ & & \\
\hline KMO & .684 & \\
\hline P_value & .000 & \\
\hline TVE(\%) & 66.689 \\
\hline \multicolumn{2}{|c|}{ Source: The authors synthesize and calculate (2021) } \\
\hline
\end{tabular}

Source: The authors synthesize and calculate (2021)
The results of the table above show that the number of factors drawn is 2 with the loading coefficients in each factor greater than 0.5 , so it has good statistical significance. The first factor is Possibility and the second is Severity. The coefficients $\mathrm{KMO}=0.684>0.5$ and $\mathrm{Sig}=0.000$ show a high level of significance of the model. The total variance extracted is $66.689 \%>50 \%$.

\subsection{Regression results}

After running the regression model with SPSS software for the first time, the research team drew the following conclusions:

Firstly, most of the independent demographic variables such as Gender, Age, Occupation, Education, Duration of Residence and Number of Family Members are not significant for the change in perception of disaster risk (including 
Tam T. Le et.al. The impact of financial preparation and disaster experience on households' disaster risk perception: empirical evidence from Quang Binh Province, Vietnam.

likelihood and severity) in this study. Since natural disasters affect everyone, there is no significant difference in disaster risk perception among people of different genders, ages, etc. This was expected by the research team in advance, so the demographic variables will be removed in the next run of the regression model.

Second, the variable Income Diversity has a rather large $P_{-}$value in the models, so it will also be removed in the next run. The reason is that in Quang Binh province, up to $83 \%$ of households have less than 2 sources of income or more. The majority of households have only one source of income, so the difference in disaster risk perception among households with different number of income sources is not significant.

Third, the same Loan variable also has a large $P_{-}$value, indicating that this variable is not significant and should be removed from the model. This problem may be because when a flood occurs, all residents in the area are affected, borrowing from relatives and friends becomes more difficult for most households. Therefore, it is difficult to find a difference in disaster risk perception among households with different borrowing capacity.

Fourth, the Disaster Insurance variable was also excluded from the regression model in the next run of the research team. The reason may be that disaster insurance has not been widely introduced to people in the locality where the study was conducted, $95 \%$ of households do not buy this type of insurance.

After removing the inconsistent variables, the research team gave the final results in the following table.

Table 5: Results of the regression model

\begin{tabular}{|l|l|l|l|l|l|l|}
\hline Variable & \multicolumn{2}{l}{ POSSIBILITY } & \multicolumn{2}{l|}{ SEVERITY } \\
\hline & $\mathbf{( 1 )}$ & $\mathbf{( 2 )}$ & $\mathbf{( 3 )}$ & $\mathbf{( 4 )}$ & $\mathbf{( 5 )}$ & $\mathbf{( 6 )}$ \\
\hline $\mathrm{C}$ & 3.576 & 2.231 & 4.817 & 2.834 & 2.363 & 4.538 \\
& $(.000)$ & $(.000)$ & $(.000)$ & $(.000)$ & $(.000)$ & $(.000)$ \\
\hline Income & -.255 & & -.337 & -.048 & & -.161 \\
& $(.000)$ & & $(.000)$ & $(.079)$ & & $(.000)$ \\
\hline Deposits & -.221 & & -.052 & -.096 & & -.329 \\
& $(.043)$ & & $(.037)$ & $(.076)$ & & $(.004)$ \\
\hline Loans from financial institutions & -.127 & & -.203 & -.248 & & -.352 \\
& $(.195)$ & & $(.047)$ & $(.012)$ & & $(.000)$ \\
\hline Social insurance & -.339 & & -.573 & -.110 & & -.431 \\
& $(.078)$ & & $(.004)$ & $(.068)$ & & $(.035)$ \\
\hline Experience & .267 & .419 & & .367 & .478 & \\
& $(.000)$ & $(.000)$ & & $(.000)$ & $(.000)$ & \\
\hline Number of observations & 308 & 308 & 308 & 308 & 308 & 308 \\
\hline R-squared & .370 & .287 & .309 & .388 & .366 & .274 \\
\hline
\end{tabular}

Compare the impact of financial preparation and disaster experience on the households' perceptions of disaster risk:

The coefficient of determination Rsquared in model 2 and model 3 is .287 and .309 , respectively, showing that experience and financial preparedness variables explain $28.7 \%$ and $30.9 \%$, respectively. The action of the dependent variable Possibility. Thus, the impact of financial preparedness and disaster experience on perception of disaster possibility is roughly the same.

The coefficients of determination Rsquared in model 5 and model 6 are .366 and .274, respectively, showing that experience and financial preparedness variables explain $36.6 \%$ and $27.4 \%$, respectively. of the dependent variable Severity. It can be seen that disaster experience has a greater impact on risk perception in terms of severity than financial preparedness. The more experienced households are, the more acutely aware they are when it comes to the severity of disasters.

From the regression model results table, some discussions about the model's variables can be drawn:

Regarding the Income variable, the coefficient bears a negative sign similar to 
Tam T. Le et.al. The impact of financial preparation and disaster experience on households' disaster risk perception: empirical evidence from Quang Binh Province, Vietnam.

the model's expectations, indicating that the household income is inversely related to the perception of disaster risk. Households with higher incomes, the more subjective they are, less worry about the likelihood of happening and the level of serious damage caused by natural disasters to those households.

Regarding the Deposit variable, the coefficients are negative sign respectively $.221 ;-.052 ;-.096$ and -.329 imply that similar to income amounts, the more financially viable households, having savings deposits, the lower their perception of disaster risk. The results of running the model were similar to the group's initial expectation.

Regarding the Loans from credit institutions variable, the coefficients have negative signs as proposed. Households that cannot afford to borrow from credit institutions when natural disasters occur are subject to more concern about natural disaster risks.
Regarding the Social Insurance variable, the inverse correlation of this variable with the dependent variable Possibility and severity is shown through the coefficients respectively -.339; -.573; .110 and -.431 . A household's poor ability to afford social insurance types will lead to an increase in disaster risk perception in terms of both likelihood and severity.

Regarding the variable of Experience, the signs of the coefficients are all positive signs, consistent with the model's hypothesis, showing that the stronger the households experienced the natural disaster, the more serious the damage, the more their perception will be large on the next possibility of natural disasters as well as its consequences on people's lives.

The research team has summarized the hypothesis and conclusions about the variables in the following table:

Table 6: Results of the sign of the variables in the model compared with hypothesis

\begin{tabular}{|c|c|c|c|c|}
\hline & Variable name & Hypothesis & Result & Conclude \\
\hline \multirow{7}{*}{ Financial preparation } & Diversity of income sources & $(-)$ & $(+)$ & Rejected \\
\hline & Income & $(-)$ & $(-)$ & Accept \\
\hline & Deposits & $(-)$ & $(-)$ & Accept \\
\hline & Loan from financial institutions & $(-)$ & $(-)$ & Accept \\
\hline & Borrows & $(-)$ & $(-)$ & Rejected \\
\hline & Social insurance & $(-)$ & $(-)$ & Accept \\
\hline & Disaster insurance & $(-)$ & $(-)$ & Rejected \\
\hline Disaster Experiences & Experience & $(+)$ & $(+)$ & Accept \\
\hline
\end{tabular}

\section{Recommendations}

From the issues discussed in the previous chapters, the research team has discussed and proposed some recommendations for authorities and people in areas affected by natural disasters, as follows:

\section{For the authorities:}

(1). With comments from the research model that the deeper households experience with natural disasters, the higher their perception of disaster risk. Therefore, the authorities, particularly The Official of Central Steering Committee for Natural Disaster Prevention and Control in the localities, need to organize dissemination and propaganda to raise awareness in the community about disaster prevention and control through information on disaster experiences. Data and figures of the damages caused by natural disasters contribute to raising awareness of the people on this issue. Each branch and locality should integrate into their own development investment programs the work of natural disaster prevention and control. In addition, this propaganda should also be spread to schools. Schools should have programs to increase the education of students from the start of school on disaster issues, and to integrate disaster 
Tam T. Le et.al. The impact of financial preparation and disaster experience on households' disaster risk perception: empirical evidence from Quang Binh Province, Vietnam.

prevention skills into teaching. Schools can integrate disaster lessons into extracurricular activities to make it easier for students to access.

(2). With the comment on the impact of the ability to borrow from financial institutions on disaster risk perception, the research team has a recommendation for the Vietnam Bank for Social Policies (VBSP) to create products support people who cannot afford to borrow from other credit institutions. This is a vulnerable person after a natural disaster, needs special financial help to be able to rebuild life. The Vietnam Bank for Social Policies at the provincial and district levels should continue to have the attention and support through credit programs and loan policies to develop economy, stabilize production and quickly stabilize life. Priority is given to people in severely affected areas after natural disasters. Specifically, the proposal allows increasing the lending limit and expanding the number of near-poor households to borrow under the loan program for poor households to build houses to prevent floods and storms. In addition, it is possible to propose a lengthening of this concessional loan program. In addition, financial support solutions for people in areas affected by natural disasters also mobilize help from the community through the Vietnam Fatherland Front and the Red Cross, loans and aid sources from international organizations such as Asian Development Bank (ADB), World Bank or Japan International Cooperation Agency (JICA)....

(3). According to the research team survey, less than 5\% of households in Quang Binh have purchased natural disaster insurance for the most part because they do not know this insurance. Due to the low penetration of natural disaster insurance in the community when normally the participants are mainly commercial assets of companies, large- scale enterprises, microfinance institutions need to pay attention. important in disseminating and widely introducing people in areas prone to natural disasters about the features and benefits of using this type of insurance, thereby reducing the financial burden when risks occurs

For people in areas affected by natural disasters:

Besides the objective and scientific causes of natural disasters, there are also subjective human factors due to strong urbanization and rapid economic growth. Specifically, the state of deforestation for economic development has not been strictly controlled; unreasonable construction of hydropower, irrigation works, ... from planning and project formulation process, leading to a negative impact on downstream areas; does not consider geological and geomorphological factors when investing in the construction of architectural works, infrastructure that changes the topography, easily causing the instability of geological structures, ... Investment in areas susceptible to natural disasters should ensure that the construction of development investment such as the construction of hydropower projects, mountain traffic works, power transmission lines, ... must be associated with countermeasures dealing with climate change, researching and evaluating the impacts of buildings on the natural environment, balancing economic development opportunities and disaster risks. All people in areas vulnerable to the impacts of natural disasters need cooperation and willingness to coordinate with authorities in propagating and educating about prevention and consequences of natural disasters to strengthen the capacity to prevent and respond.

\section{Limitations}

Research results can contribute positively to the policy making of authorities in the coming time, however, the 
Tam T. Le et.al. The impact of financial preparation and disaster experience on households' disaster risk perception: empirical evidence from Quang Binh Province, Vietnam.

research topic still has certain limitations, such as small sample size in one province of Quang Binh, not many in-depth interviews. In addition, the aspect of "disaster experiences" do not cover intangible assets.

\section{ACKNOWLEDGEMENT}

This paper is performed within the Ministrial Scientific Research Project "A Study on Conditions for Developing Fintech Ecosystem to Promote Finncial Inclusion in Vietnam/Nghiên cứu điều kiện phát triển hệ sinh thái Fintech thúc đẩy tài chính toàn diện ở Việt Nam”, Code B2021.KHA.04.

\section{Conflict of Interest: None}

\section{Source of Funding: None}

\section{REFERENCES}

1. Armas, I. (2006). Earthquake risk perception in Bucharest, Romania. Risk Analysis, 26, 1223-1234.

2. Barnett, J., Breakwell, G.M. (2001). Risk perception and experience: hazard personality profiles and individual differences. Risk Analysis, 21(1), 171-178.

3. Becker, J.S., Paton, D., Johnston, D.M., Ronan, K.R. (2012). A model of household preparedness for earthquakes: How individuals make meaning of earthquake information and how this influences preparedness. Natural Hazards, 64, 107137.

4. Botzen, W.J.W., Aerts, J.C.J.H. \& van den Bergh, J.C.J.M. (2009). Dependence of flood risk perceptions on socioeconomic and objective risk factors. Water Resources Research, 45:W10440

5. Brody, S. D., S. Zahran, A. Vedlitz, \& H. Grover. (2008). Examining the Relationship between Physical Vulnerability \& Public Perceptions of Global Climate Change in the United States. Environment and Behavior, 40(1), 72-95.

6. Bubeck, P., Botzen, W.J.W. \& Aerts, J.C.J.H. (2012). A Review of Risk Perceptions and Other Factors that Influence Flood Mitigation Behavior. Risk Analysis, 32, 1481-1495.

7. Doyle, E.E.; McClure, J.; Potter, S.H.; Becker, J.S.; Johnston, D.M.; Lindell, M.K.; Johal, S.; Fraser, S.A.; Coomer, M.A.
(2018). Motivations to prepare after the 2013 Cook Strait Earthquake, N.Z. J. Disaster Risk Reduction, 31, 637-649.

8. Floyd DL, Prentice-Dunn S, Rogers RW (2000). A meta-analysis of research on protection motivation theory. Journal of Applied Social Psychology; 30(2):407-429.

9. Finucane, M. L., P. Slovic, C. K. Mertz, J. Flynn, and S. A. Theresa. (2000). Gender, Race, and Perceived Risk: The 'White Male' Effect. Health, Risk \& Society, 2(2), 159-172.

10. Grothmann, T. \& Reusswig, F. (2006). People at risk of flooding: why some residents take precautionary action while others do not. Natural Hazards, 38(1-2), 101-120.

11. Hamilton, L. C. (2011). Education, Politics and Opinions about Climate Change Evidence for Interaction Effects. Climatic Change, 104(2), 231-242.

12. Harlan, Sharon L.; Sarango, Mariana J.; Mack, Elizabeth A.; Stephens, Timothy A. (2019). A Survey-Based Assessment of Perceived Flood Risk in Urban Areas of the United States. Anthropocene.

13. Han, Z., Wang, H., Du, Q. \& Zeng, Y. (2017). Natural hazards preparedness in Taiwan: A comparison between households with and without disabled members. Health Security.

14. Helweg-Larsen, M. (1999). (The lack of) optimistic biases in response to the 1994 northridge earthquake: The role of personal experience. Basic and Applied Social Psychology, 21, 119-129.

15. Keil, A., Zeller, M., Wida, A., Sanim, B., Birner, R. (2008). What determines farmers' resilience towards ENSO-related drought? An empirical assessment in central Sulawesi, Indonesia. Clim Chang, 86, 291307.

16. Kron, W.(2002) : Flood risk = hazard $\times$ exposure $\times$ vulnerability, in: Flood defence, edited by: Wu, B., Wang, Z., Wang, G., Huang, G., Fang, H., and Huang, J., Science Press, New York.

17. Lawrence, J., Quade, D. \& Becker, J. (2014). Integrating the effects of flood experience on risk perception with responses to changing climate risk. Natural Hazards, 74, 1773-1794.

18. Le Dang, H., Li, E., Nuberg, I., Bruwer, J. (2014). Farmers' assessments of private adaptive measures to climate change and 
Tam T. Le et.al. The impact of financial preparation and disaster experience on households' disaster risk perception: empirical evidence from Quang Binh Province, Vietnam.

influential factors: A study in the Mekong Delta, Vietnam. Natural Hazards, 71, 385401.

19. Lindell, M.K. (2013). North American Cities at Risk: Household Responses to Environmental Hazards; Joffe, H., Rossetto, T., Adams, J., Eds.; Springer: New York, NY, USA, 109-130.

20. Lindell, M.K., Whitney, D.J. (2000). Correlates of household seismic hazard adjustment adoption. Risk Analysis, 20, 1325.

21. Linden, S.L., Leiserowitz, A.A., Feinberg, G.D., \& Maibach, E.W. (2015). The Scientific Consensus on Climate Change as a Gateway Belief: Experimental Evidence. PLOS ONE, 10(2), e0118489.

22. Lo, A.Y. (2013). The role of social norms in climate adaptation: Mediating risk perception and flood insurance purchase. Glob. Environ. Chang, 23, 1249-1257.

23. Lo, A.Y., Cheung, L.T.O., (2015). Seismic risk perception in the aftermath of Wenchuan earthquakes in Southwestern China. Natural Hazards, 78, 1979-1996.

24. McCright, A. M. (2010). The Effects of Gender on Climate Change Knowledge and Concern in the American Public. Population and Environment, 32(1), 66-87.

25. Miceli, R., Sotgiu, I., Settanni, M. (2008). Disaster preparedness and perception of flood risk: A study in an alpine valley in Italy. Journal of Environmental Psychology, 28, 164-173.

26. Michael K. Lindell; David J. Whitney. (2000). Correlates of Household Seismic Hazard Adjustment Adoption, 20(1), 13-26. doi:10.1111/0272-4332.00002

27. O’Connor, R. E., R. J. Bord, \& A. Fisher. (1999). Risk Perceptions, General Environmental Beliefs, and Willingness to Address Climate Change. Risk Analysis, 19(3), 461-471.

28. Paton, D. \& Johnston, D. (2001). Disasters and communities: Vulnerability, resilience and preparedness. International Journal of Disaster Risk Management, 10, 270-277.

29. Paul, B.K.; Bhuiyan, R.H. (2010). Urban earthquake hazard: Perceived seismic risk and preparedness in Dhaka city, Bangladesh. Disasters, 34, 337-359.

30. Raaijmakers, R., Krywkow, J. R., and van der Veen, A.(2008) : Flood risk perceptions and spatial multi-criteria analysis: An exploratory research for hazard mitigation, Nat. Hazards, 46, 307-322.

31. Ronald W. Rogers. (1975). A Protection Motivation Theory of Fear Appeals and Attitude Change1, The Journal of Psychology: Interdisciplinary and Applied, 91:1, 93-114.

32. Rogers RW. (1983) Cognitive and physiological processes in fear appeals and attitude change: A revised theory of protection motivation. In Cacioppo BL, Petty RE (eds). Social Psychophysiology: A Sourcebook. London: Guilford Press.

33. Sjoberg, L. (2000). Factors in Risk Perception. Risk Analysis, 20(1), 1-12.

34. Slovic (1987). P. Perception of risk. Science; 236:280-285.

35. Slovic, P. (1999). Trust, Emotion, Sex, Politics, and Science: Surveying the RiskAssessment Battlefield. Risk Analysis, 19(4), 689-701.

36. Solberg, C., Rossetto, T. \& Joffe, H. (2010). The social psychology of seismic hazard adjustment: re-evaluating the international literature. Natural Hazards and Earth System Sciences, 10(8), 16631677.

37. Spence, A., W. Poortinga, C. Butler, \& N. F. Pidgeon. (2011). Perceptions of Climate Change and Willingness to Save Energy Related to Flood Experience. Natural Climate Change, 1(1), 46-49.

38. Sun, Y., Han, Z. (2018). Climate Change Risk Perception in Taiwan: Correlation with Individual and Societal Factors. International Journal of Environmental Research And Public Health, 15, 91.

39. Sund, B., M. Svensson, and H. Andersson. (2015). Demographic Determinants of Incident Experience and Risk Perception: Do High-Risk Groups Accurately Perceive Themselves as High-Risk?. Journal of Risk Research, 9877, 1-19.

40. Sundblad, E., A. Biel, \& T. Gärling. (2007). Cognitive and Affective Risk Judgements Related to Climate Change. Journal of Environmental Psychology, 27(2), 97-106.

41. Wachinger G, Renn O, Begg C, Kuhlicke C. (2013). The risk perception paradoximplications for governance and communication of natural hazards. Risk Analysis. 33(6), 1049-1065.

42. Weinstein, N.D. (1989). Effects of personal experience on self-protective behavior. Psychological Bulletin, 105(1), 31-50. 
Tam T. Le et.al. The impact of financial preparation and disaster experience on households' disaster risk perception: empirical evidence from Quang Binh Province, Vietnam.

43. White GF. (1945) Human Adjustment to Floods - A Geographical Approach to the Flood Problem in the United States.Chicago: University of Chicago, 1945 White GF. Human Adjustment to Floods A Geographical Approach to the Flood Problem in the United States. Chicago: University of Chicago.

44. Whitmarsh, L. (2008). Are flood victims more concerned about climate change than other people? The role of direct experience in risk perception and behavioural response. Journal of Risk Research, 11(3), 351-374.

45. Wim Kellens; Teun Terpstra; Philippe De Maeyer. (2012). Perception and Communication of Flood Risks: A Systematic Review of Empirical Research.

46. Xu, D., Yong, Z., Deng, X., Liu, Y., Huang, K., Zhou, W., Ma, Z. (2019). Financial preparation, disaster experience, and disaster risk perception of rural households in earthquake-stricken areas: Evidence from the Wenchuan and Lushan earthquakes in China's Sichuan Province. International
Journal of Environmental Research And Public Health, 16, 3345.

47. Xu, D.D., Peng, L., Liu, S.Q. \& Wang, X.X. (2018). Influences of Risk Perception and Sense of Place on Landslide Disaster Preparedness in Southwestern China. Journal of Disaster Risk Science, 9, 167180.

48. Xu, D.D.; Peng, L.; Liu, S.Q.; Su, C.J.; Wang, X.X.; Chen, T.T. (2016). Influences of mass monitoring and mass prevention systems on peasant households' disaster risk perception in the landslide-threatened Three Gorges Reservoir area, China. Habitat International, 58, 23-33.

How to cite this article: Tam T. Le, Trang T.H. Thai, Thao P. Do et.al. The impact of financial preparation and disaster experience on households' disaster risk perception: empirical evidence from Quang Binh Province, Vietnam. International Journal of Research and Review. 2021; 8(5): 344-356. DOI: https://doi.org/10. 52403/ijrr.20210544 